\title{
BATU LONCENG SEBAGAI PENGINGAT BENCANA DI SESAR LEMBANG: KAJIAN ARKEOLOGI ALTERNATIF
}

\author{
Batu Lonceng as a Reminder of Disaster in the Lembang Fault: \\ Alternative Archaeological Studies \\ Garbi Cipta Perdana \\ Niskala Institut \\ Komplek Citra Antapani, Jalan Citra 2 nomor 7, Kecamatan Antapani, \\ Kota Bandung, Jawa Barat 40291 \\ E-mail: gerbycipta@gmail.com
}

\begin{abstract}
Batu Lonceng Site is located in West Bandung Regency, West Java Province and is located right on the Lembang Fault. This research uses alternative archaeological studies that appear to be a "comparisons" to mainstream archeology, based on the Charles Sanders Peirce's semiotic theory. This research aims to reveal the function and meaning of the bell stone based on alternative archeology. Alternative archeology itself is the impact of the "saturation" of society on various unpublished studies. This makes people interpret the archaeological remains around them in their own way. Therefore, the people's interpretation of the archaeological remains called Batu Lonceng is interesting to study because with it we can find out the natural thinking of the local community in constructing these artifact. Based on this studies, Batu Lonceng is a mitigation alarm that will ring as a warning of danger or disaster. This can be seen as an effort by the community to understand and interpret their environment which is very vulnerable to disaster.
\end{abstract}

Keywords: Batu Lonceng Site, alternative archeology, semiotic, Lembang Fault, mitigation

\begin{abstract}
Abstrak
Situs Batu Lonceng teletak di Kabupaten Bandung Barat, Provinsi Jawa Barat dan keletakannya tepat berada di Sesar Lembang. Penelitian ini merupakan kajian arkeologi alternatif yang muncul sebagai "pembanding" dari archaeological mainstream, dengan mengunakan landasan teori semiotika Charles Sanders Peirce. Penelitian ini bertujuan untuk mengungkap fungsi dan makna Batu Lonceng berdasarkan arkeologi alternatif. Arkeologi alternatif sendiri merupakan dampak dari "kejenuhan" masyarakat terhadap berbagai penelitian yang tidak dipublikasikan. Hal itu membuat masyarakat membuat interpretasi sendiri terhadap tinggalan arkeologi yang ada di sekitar mereka dengan cara mereka sendiri. Oleh karena itu, interpretasi masyarakat terhadap tinggalan arkeologi yang disebut Batu Lonceng menjadi menarik untuk dikaji karena dengan itu kita dapat mengetahui alam pikir masayarakat setempat dalam mengkonstruksi tinggalan tersebut. Berdasarkan kajian ini batu lonceng merupakan suatu alarm mitigasi yang akan berdentang sebagai peringatan ada mara bahaya atau bencana. Hal tersebut dapat dilihat sebagai upaya masyarakat mamahami dan memaknai lingkungannya yang sangat bepontensi tertimpa bencana.
\end{abstract}

Kata Kunci: Situs Batu Lonceng, arkeologi alternatif, semiotika, Sesar Lembang, mitigasi

\section{PENDAHULUAN}

Gempa bumi adalah peristiwa terjadinya pergerakan/pergeseran lapisan batuan pada kulit bumi secara tiba-tiba akibat pergerakan lempeng-lempeng tektonik yang mengakibatkan bumi bergetar atau bergoncang. Gempa bumi yang disebabkan oleh aktivitas pergerakan lempeng tektonik disebut gempa bumi tektonik. Sementara itu, gempa bumi yang terjadi akibat aktifitas gunung berapi disebut sebagai gempa bumi vulkanik (Sunarjo dkk., 2012:26). Menurut Sabtaji, rata-rata aktivitas gempa tektonik di Indonesia dalam rentang tahun 2009 
hingga tahun 2019 adalah sebanyak 6.512 kejadian per tahun, atau 543 kejadian per bulannya, dan 18 kejadian gempa per harinya jika dibulatkan (2020:3). Bahkan disaat penulis sedang merampungkan tulisan ini, setidaknya sudah terjadi sedikitnya tiga kali gempa yang terjadi dan dirasakan oleh masyarakat Bandung. Hal itu menegaskan bahwa Indonesia berada pada daerah yang rawan sekali tertimpa gempa bumi.

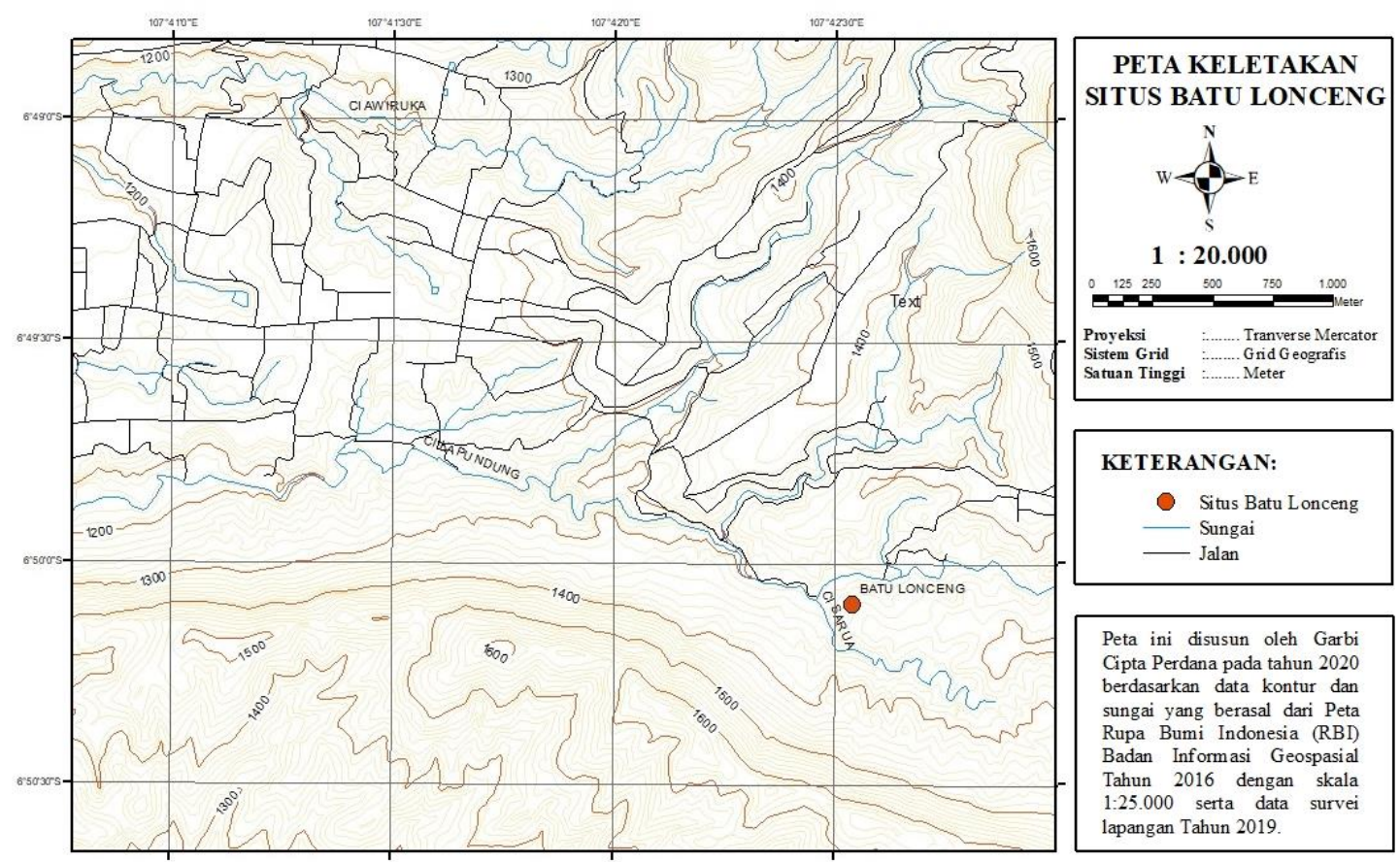

Gambar 1. Peta Keletakan Situs Batu Lonceng

Situs Batu Lonceng terlelak di Kampung Batu Lonceng, Desa Sunten Jaya, Kabupaten Bandung Barat, Provinsi Jawa Barat. Lokasi Situs Batu Lonceng tepat berada pada jalur Sesar Lembang. Berdasarkan Laporan Hasil Penelitian Penanggulangan Kasus Arkeologi di Sekitar Cekungan Bandung yang diterbikan oleh Balai Arkeologi Bandung, situs ini dikenal dengan nama Keramat Batu Lonceng. Situs ini berada pada puncak bukit di sebelah selatan kampung dengan ketinggian 1437 mdpl dengan posisi kordinat pada 06 50 '19,3" LS dan $107^{\circ} 42^{\prime} 32,3$ " (Gambar 1). Situs ini terdiri atas tiga teras yang mana pada bagian barat dan selatan teras paling bawah terdapat sejumlah makam yang ditandai dengan nisan berbentuk pipih panjang. Pada teras tengah dan atas terdapat sejumlah batu berdiri. Pada bagian timur teras atas terdapat bangunan semi-permanen yang di dalamnya tersimpan batu berbentuk oval bertingkat yang terlihat antropomirfik namun masih sederhana. Oleh masyarakat setempat batu tersebut diberi nama batu lonceng (Widyastuti dkk., 2006:11-12). Adapun menurut Perdana dan Wanny Situs Batu Lonceng merupakan suatu kabuyutan yang di dalamnya terdapat tinggalan berupa menhir serta arca tipe polinesia (2020:10).

Objek ilmu arkeologi pun tak pernah bergerak dengan sendirinya, namun permasalahan penelitian dalam arkeologi senantiasa "bergerak" untuk dapat dikembangkan ataupun diberikan perspektif baru (Sedyawati, 2012:3). 
Tulisan ini dimaksudkan untuk mengetahui hubungan antara Situs Batu Lonceng dengan lingkungan sekitar situs tersebut berada, yaitu pada jalur Sesar Lembang yang masih aktif bergeser sehingga rentan memicu gempa bumi. Selain itu, dalam upaya untuk memenuhi tujuan tersebut, digunakan pendekatan arkeologi alternatif yang "mendemokratisasi arkeologi" dengan memberi ruang untuk bersuara (interpretasi) bagi masyarakat, dalam hal ini masyarakat sekitar Situs Batu Lonceng.

Menurut Marwoto-Johan, istilah arkeologi alternatif pertama kali digunakan oleh Tim Scadla-Hall dalam artikelnya yang berjudul The Comfort of Unreason: The Importnace and Relevance of Alternative Archaeology pada tahun 2004. Ada pun perspektif arkeologi alternatif merupakan pandangan yang menyadari bahwa ahli arkeologi bukanlah pemilik tunggal otoritas keilmuan. Interpretasi tunggal tidak dapat lagi dipertahankan karena interpretasi masa lalu tentu akan beragam, dan merupakan kontestasi. Hal itu tidak dapat lepas dari keberadaan benda masa lalu (objek arkeologi) yang hadir bersama dengan benda masa kini yang harus bermanfaat di masa depan. Dengan begitu diharapkan tulisan ini dapat menyajikan perspektif baru yang lebih nyata dan "dekat" dengan kehidupan masyarakat. Sebab, sudah seharusnya arkeologi masa kini menjadi arkeologi yang berorientasi pada masyarakat, sehingga para ahli arkeologi dituntut untuk menyampaikan hasil interpretasinya kepada masyarakat dan melibatkan masyarakat menjadi partner dalam mencapai tujuan penelitian (Marwoto-Johan, 2012:113, 118).

\section{HASIL DAN PEMBAHASAN \\ Sesar Lembang}

Provinsi Jawa Barat terkenal dengan potensi wisata, salah satunya daerah destinasi wisata yang cukup popular adalah Lembang di Kabupaten Bandung Barat. Kawasan Lembang merupakan kawasan yang memiliki potensi besar sebagai sentra pertanian, peternakan, dan pariwisata. Akan tetapi, dari segi kondisi geologi, kawasan Lembang merupakan kawasan yang rawan gempa karena posisinya yang berada diantara oleh Gunung Tangkuban Perahu yang masih aktif serta Sesar Lembang yang sama aktifnya dengan bukti adanya gempa bumi yang masih terjadi (Fahrurijal dkk.., 2020: 2; Rasmid, 2014: 136).

Istilah sesar, yang dalam bahasa Inggris disebut dengan fault merupakan retakan di kerak Bumi yang mengalami pergeseran atau pergerakan. Terdapat tiga jenis sesar yang umum dikenal, yaitu sesar normal (normal fault), sesar naik (reverse fault), dan sesar geser mendatar (strike-slip fault). Sesar Lembang merupakan suatu sesar yang membentuk retakan tektonik sepanjang $29 \mathrm{~km}$ (Gambar 2). Sesar tersebut masuk kedalam jenis sesar normal. Pada bagian utara sesar Lembang, yaitu daerah dari Lembang ke barat hingga Cisarua arah geraknya relatif turun, sedangkan pada bagian selatan, yaitu dari Maribaya ke timur hingga Batulonceng bergerak terangkat ke atas. Proses tektonik ini mengakibatkan terbentangnya suatu gawir (lereng lurus) yang merupakan bidang gelincir Sesar Lembang yang dapat jelas terlihat dari Lembang ke arah timur (Brahmantyo, 2011:8; Daryono, 2016:148).

Daryono dalam disertasinya yang berjudul Paleoseismologi Tropis Indonesia dengan

studi kasus di Sesar Sumatra, Sesar Palukoro-Matano, dan Sesar Lembang berhasil menganalisa pergerakan Sesar Lembang berdasarkan pergeseran sungai dan stratigrafinya. Kecepatan gerak Sesar Lembang adalah 3-5.5 mm/tahun. Dengan begitu sesar ini mampu menghasilkan gempa bumi dengan kekuatan magnitude 6.5-7. Selain itu, berdasarkan hasil 
uji puritan yang dilakukannya, diketahui bawa pernah terjadi gempa bumi pada abad 15 sekitar tahun 1450-1460 (2016:iv). Ada pun daerah yang menjadi lokasi dengan kerentanan paling tinggi dari dampak gempa bumi yang dihasilkan Sesar Lembang adalah daerah Lembang karena posisinya yang ada pada lintasan sesar atau sangat dekat dengan sumber gempa (Handayani dkk., 2009:337).

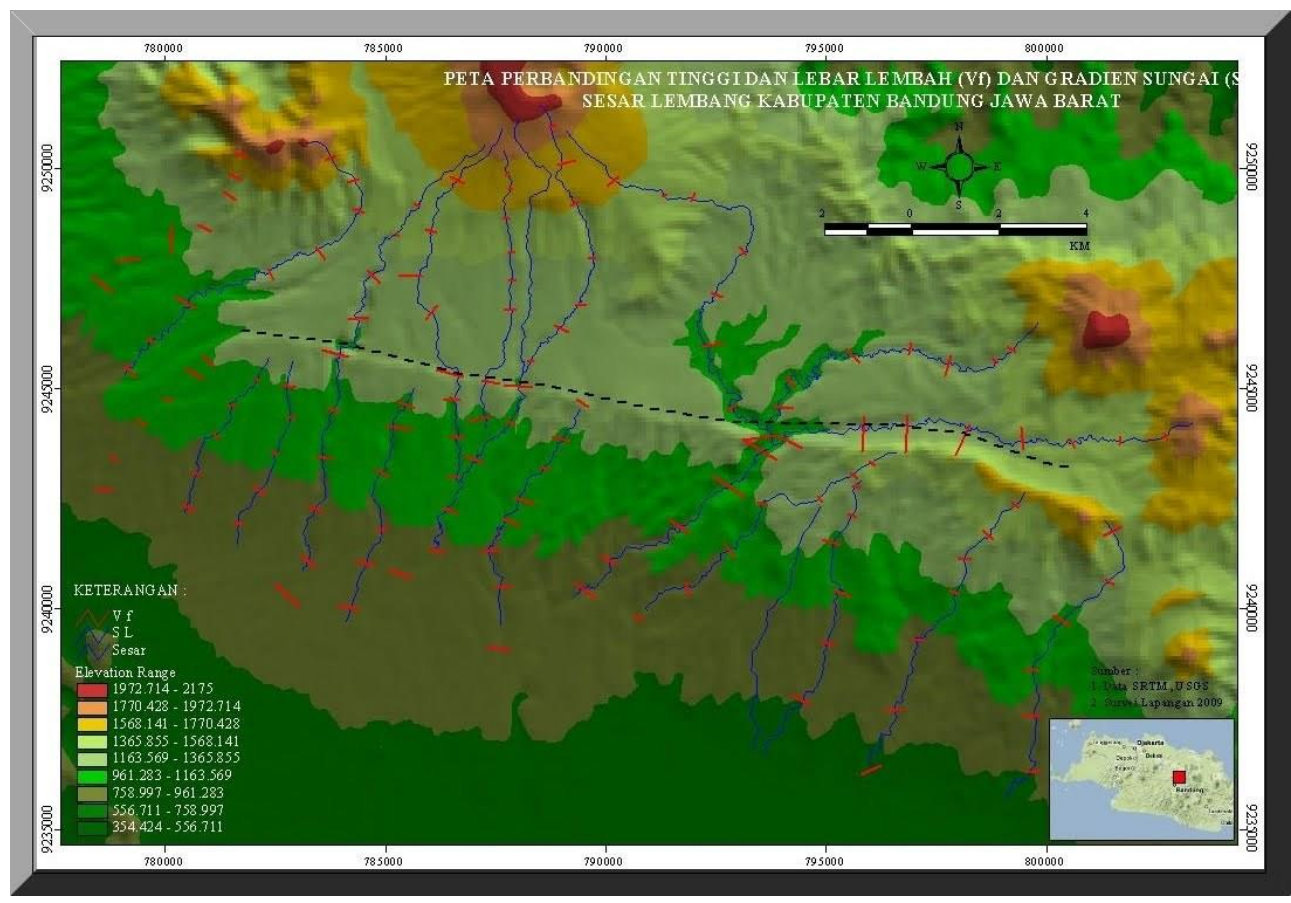

Gambar 2. Sesar Lembang di Jawa Barat (Sumber: Achmad Hidayaht, 2016).

\section{Situs Batu Lonceng IMenurut Masyarakat}

Menurut cerita yang beredar di masyarakat, Situs Batu Loceng ditemukan saat diadakan pembukaan lahan penanaman kopi untuk kepentingan pemerintah Kolonial Belanda. Pada daerah tersebut ditemukan sebuah makam dengan panjang 4,5 meter dengan kepala yang mengarah ke timur. Masyarakat sekitar menganggap makam ini merupakan peninggalan Sunan Marga Taka atau Prabu Sang Wanara (Ciung Wanara). Makam tersebut dibuat ketika Sunan Marga Taka tengah bersembunyi. Dalam persembunyiannya ia membuat padepokan untuk belajar ilmu bela diri dan menyebarkan agama Islam (Maulana, 2019).

Pada situs ini terdapat pula artefak yang disebut Batu Lonceng (Gambar 3). Artefak batu yang bentuknya menyerupai lonceng tersebut, dipercayai oleh masyarakat sekitar sebagai Jabang Bayi Gada Sewu Liman. Selain bentuknya yang menyerupai lonceng, oleh masyarakat batu tersebut dipercaya dapat berdentang ketika dalam keadaan tertentu namun bunyi peringatan tersebut hanya bisa didengar oleh penduduk Suntenjaya saja. Salah satu cerita yang dipercaya oleh masyarakat sekitar terjadi ketika zaman penjajahan Jepang dan Belanda. Peringatan tersebut terjadi sesaat sebelum musuh hendak datang menyerang, dengan begitu masyarakat pun telah siap siaga sebelum diserang. Selain itu, Batu Lonceng pun memiliki keunikan, yaitu tidak sembarang orang dapat mengangkatnya. Terdapat kepercayaan bahwa jika seseorang berhasil mengangkat Batu Lonceng maka keinginan dia akan terpenuhi atau memiliki masa depan yang bagus. (Entis, 2014; Maulana, 2019; Sukma, 2018). 


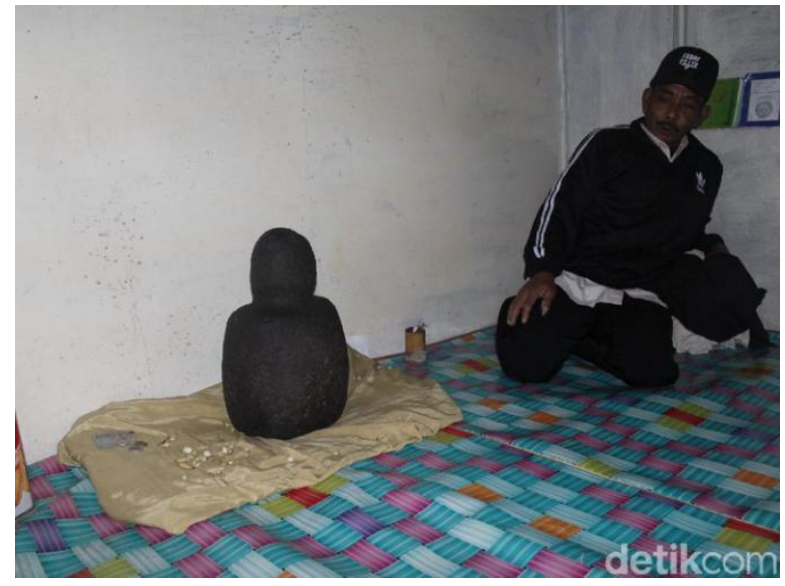

Gambar 3. Batu Lonceng

Sumber: Yudha Maulana/detikcom, 2019

\section{Batu Lonceng Sebagai Pengingat Bencana Sesar Lembang}

Menurut Munandar, perspektif semiotika Charles Sanders Peirce dapat digunakan untuk melihat artefak, sehingga artefak tersebut dapat dianggap sebagai suatu tanda (sign) yang mempunyai acuan (referent). Pertalian antara sign dan referent tersebut melahirkan interpretant yang berupa konsep tertentu (Munandar, 2004:58). Dengan menggunakan teori semiotika Peirce Batu Lonceng direpresentasikan sebagai tanda. Apakah sebagai ikon, indeks ataukah sebagai simbol. Ikon merupakan hubungan kemiripan tanda atau hasil peniruan bentuk dari berbagai sumber dengan apa yang dimaknainya. Indeks merupakan hubungan kontiguitas atau hubungan 'yang menunjukan'. Simbol merupakan tanda yang dimaknai atas dasar konvensi sosial (Saidi, 2017:47).

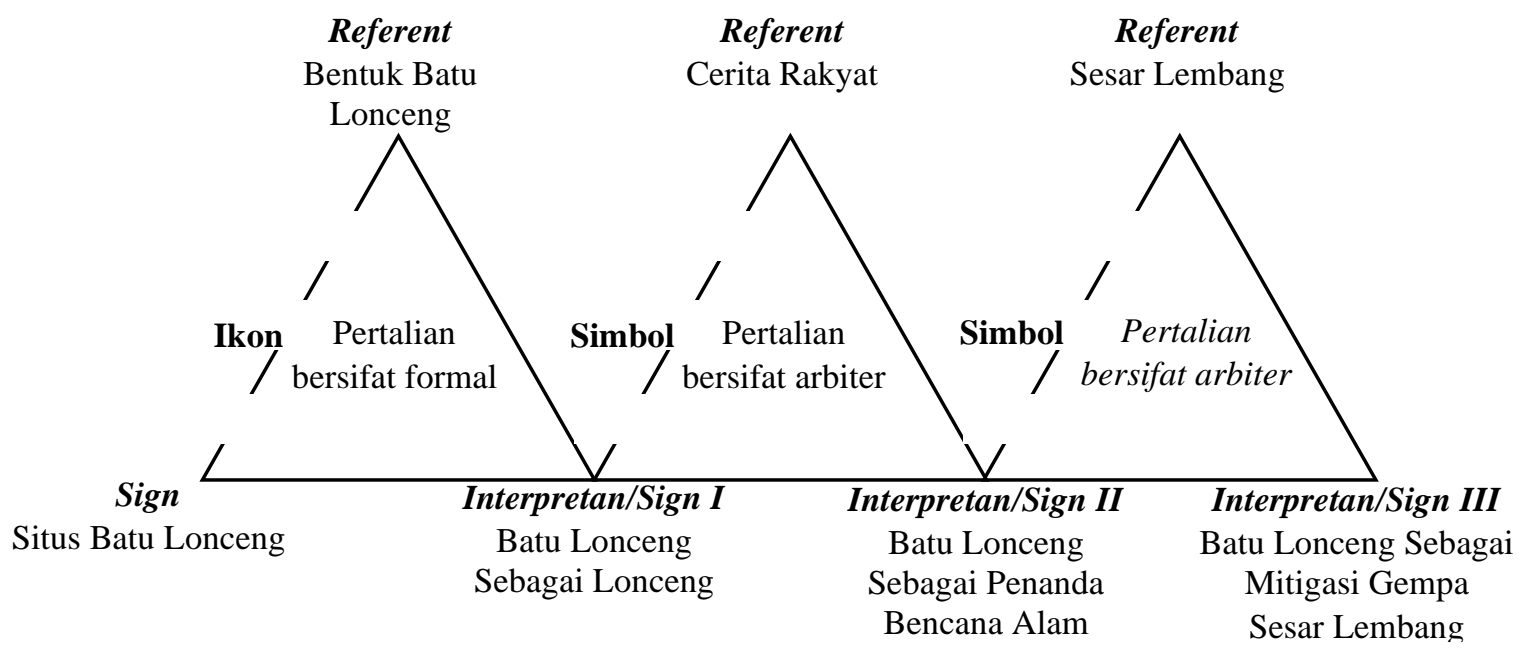

Gambar 4. Semiosis Batu Lonceng dalam Trikotomi Peirce Sumber: Perdana, 2020

Berdasarkan (Gambar 4) dapat diketahui bahwa penamaan Situs Batu Lonceng dikarenakan pada situs tersebut terdapat suatu batu yang bentuknya mengacu pada bentuk 
lonceng. Situs Batu Lonceng tersebut merupakan sign yang mengacu pada referent bentuk lonceng. Pertalian yang terjadi antara Situs Batu Lonceng dengan bentuk artefak bentuk lonceng tersebut bersifat formal, sehingga membentuk pertalian ikon. Hubungan antara sign dengan referent tersebut memproduksi tafsiran, yaitu interpretant yang menunjukkan bahwa Batu Lonceng merupakan lonceng. Selanjutnya, interpetant tersebut menjadi sign I yang mengacu pada referent cerita rakyat yang mengisahkan bahwa Batu Lonceng akan berdentang saat akan terjadi suatu bencana. Pertalian yang terjadi antara sign I dengan referent tersebut bersifat arbiter, sehingga membentuk pertalian simbol. Hubungan antara sign dengan referent tersebut memproduksi tafsiran, yaitu interpretant yang menunjukkan bahwa Batu Lonceng merupakan penanda bencana alam. Berikutnya, interpretan tersebut menjadi sign II yang mengacu pada referent Sesar Lembang yang merupakan sesar aktif dan akibat aktifitasnya dapat memicu gempa bumi. Pertalian yang terjadi antara sign II dengan referent tersebut bersifat arbiter, sehingga membentuk pertalian simbol. Hubungan antara sign dengan referent tersebut memproduksi tafsiran, yaitu interpretant yang menunjukkan bahwa Batu Lonceng merupakan langkah mitigasi gempa di Sesar Lembang. Berdasarkan semiotika makna dari artefak Batu Lonceng dapat ditafsirkan sebagai pengingat bencana di tempatnya berada, yaitu Sesar Lembang.

\section{SIMPULAN}

Dengan menggunakan perspektif arkeologi alternatif beserta kerangka teori semiotik Peirce dapat diketahui bahwa Batu Lonceng merupakan suatu artefak yang diberi nama oleh masyarakat setempat berdasarkan pada bentuknya yang dianggap menyerupai lonceng. Hal ini berbeda dengan analisa para arekolog yang memandang bentuk artefak batu tersebut menyerupai manusia atau terlihat antropomorfik. Selama ini arkeolog seakan memegang kuasa penuh atas makna tinggalan arkeologis, sehingga dapat menentukan mana yang pantas dan mana yang tidak. Selain bentuknya yang menyerupai lonceng, oleh masyarakat artefak ini dinamai Batu Lonceng sebab dipercaya dapat berdentang selayaknya lonceng. Suara tersebut dianggap sebagai pengingat (alarm) akan terjadinya bencana.

Perspektif masyarakat dalam melihat suatu tinggalan budaya tersebut dapat dimaknai sebagai usaha memaknai lingkungannya yang rentan terhadap bencana. Letak situs yang berada pada lintasan Sesar Lembang yang aktif membuat daerah tersebut memiliki tingkat kerentanan paling tinggi. Diperkirakan kekuatan gempa yang akan terjadi akibat aktivitas Sesar Lembang dapat mencapai magnitudo sebesar 6-7.5. Dan jika benar hal itu terjadi, semoga saja Batu Lonceng akan berdentang untuk memberitahukan kepada masayarakat sekitar agar bersiap akan bencana yang akan terjadi.

\section{DAFTAR PUSTAKA}

Brahmantyo, B. (2011). Sesar Lembang, Heartquake Di Jantung Cekungan Bandung. Geo Magz 1 (1), $17-25$.

Daryono, M. R. (2016). Paleoseismologi Tropis Indonesia (Dengan Studi Kasus Di Sesar Sumatra, Sesar Palukoro-Matano, dan Sesar Lembang). In Institut Teknologi Bandung (Vol. 32411002).

Entis. (2014). Silsilah Padepoka Patilasan Batulonceng. https://www.slideshare.net/KangDhafidz/silsilah-patilasan-batuloceng 
Fahrurijal, R., Tohari, A., \& Muttaqien, I. (2020). Mikrozonasi Seismik Di Wilayah Ancaman Sesar Lembang Antara Seksi Cihideung Dan Gunung Batu Berdasarkan Pengukuran Mikrotremor. RISET Geologi Dan Pertambangan, 30(1), 81. https://doi.org/10.14203/risetgeotam2020.v30.1092

Handayani, L., Mulyadi, D., Wardhana, D. D., \& Nur, W. H. (2009). Percepatan Pergerakan Tanah Maksimum Daerah Cekungan Bandung: Studi Kasus Gempa Sesar Lembang. Jurnal Geologi Dan Sumberdaya Mineral, 19(5), 333-337.

Hidayaht, A. (2016). Studi Pemanfaatan Citra STRM (Shuttle Radar Topography Mission) Untuk Pengamatan Sesar Aktif Lembang Kab. Bandung. https://achmadhidayaht.school.blog/2016/12/29/48/

Marwoto-Johan, I. (2012). Archaeology for Whose Interpretation?: Finding Space for Alternative Archaeology in Indonesia. Public History Review, 19, 111-119. https://doi.org/10.5130/phrj.v19i0.3094

Maulana, Y. (2019). Cerita Kekuatan Magis Batu Lonceng Di Bandung BArat. DetikNews. https://news.detik.com/berita-jawa-barat/d-4490749/cerita-kekuatan-magis-batu-lonceng-dibandung-barat

Munandar, A. A. (2004). Karya Sastra Jawa Kuno Yang Diabadikan Pada Relief Candi-Candi Abad Ke-13 - 15 M. Jurnal MAKARA, Sosial Humaniora, 8(2), 54-60.

Perdana, G. C., \& Wahyudi, W. R. (2020). Rekonstruksi Lanskap Kabuyutan Bandung Utara. Purbawidya, 9(21), 1-14.

Rasmid, R. (2014). Aktivitas Sesar Lembang Di Utara Cekungan Bandung. Jurnal Meteorologi Dan Geofisika, 15(2), 129-136. https://doi.org/10.31172/jmg.v15i2.182

Sabtaji, A. (2020). Statistik Kejadian Gempa Bumi Tektonik Tiap Provinsi Di Wilayah Indonesia Selama 11 Tahun Pengamatan (2009-2019) Statistics of Tectonic Earthquake Events Each Province in Indonesia Territory for 11 Years of. 1(7), 31-46.

Saidi, A. I. (2017). Desain, Media, dan Kebudayaan. Penerbit ITB.

Sedyawati, E. (2012). Arkeologi Membidik Sasaran Yang Senantiasa Bergerak. In S. Rahardjo (Ed.), Arkeologi Untuk Publik (pp. 3-6). Ikatan Ahli Arkeologi Indonesia.

Sukma, F. (2018). Misteri di Balik Keunikan Batu Lonceng. https://ayobandung.com/read/2018/01/29/28069/misteri-di-balik-keunikan-batu-lonceng

Sunarjo, Gunawan, M. T., \& Pribadi, S. (2012). Gempabumi Edisi Populer (II). Badan Meteorologi Klimatolog dan Geofisikai.

Widyastuti, E., \& Dkk. (2006). Laporan Hasil Penelitian Penanggulangan Kasus Arkeologi di Sekitar Cekungan Bandung.

\section{HASIL DISKUSI}

\section{Pertanyaan}

1. Sri Utami (Fakultas Teknik Universitas Brawijaya):

Seandainya artefak Batu Lonceng menjadi penanda kawasan rawan bencana, maka berapa jumlah artefak Batu Lonceng yang telah ditemukan dan bagaimana distribusi/penyebarannya? Jika arkeolog dapat menemukan artefak serupa lainnya di kawasan tersebut, maka mungkin bisa menjadi bahan untuk memetakan suatu kawasan yang rawan bencana.

\section{Jawaban}


1. Dalam ilmu arkeologi khususnya paradigma pos-prosesual, kebudayaan tidak dapat dilihat secara seragam. Kebudayaan dipandang sebagai sesuatu yang unik di tiap daerah dan sangat tergantung dengan masyarakat sekitar. 